\title{
Effect of Obestatin on Bone Turnover in Normal and Obese Male Albino Rats
}

\author{
SAMA S. KHALIL, M.D. and REHAM H. IBRAHIM, M.D. \\ The Department of Physiology, Faculty of Medicine, Zagazig University, Egypt
}

\begin{abstract}
Background: Obestatin is a peptide hormone derived from the posttranslational cleavage of the same peptide precursor as ghrelin, it has been shown to regulate food intake, pancreatic, adipocyte, cardiac function as well as cell proliferation, however, to date, no studies have shown the effect of obestatin on bone turnover.
\end{abstract}

Aim of Study: This work was designed to investigate the effects of obestatin on bone metabolism in normal and obese rats and to explain the possible underlying mechanisms.

Material and Methods: Experiments conducted on 32 healthy adult male albino rats, which were randomly and equally divided into 2 groups, group I (normal) and group II [high fat diet induced obese group (HFD)]. Each group further subdivided into equal 2 subgroups: Group a (received a single intraperotoneal (ip) injection of $100 \mathrm{ml}$ saline daily for 30 consecutive days) and group $\mathrm{b}$ (daily ip injected with obestatin "1nmol/100gm BW" for 30 consecutive days). In all groups, gene expression of osteocalcin (OC), osteoprotegerin (OPG) and Receptor activator nuclear factor $\kappa \mathrm{B}$ ligand (RANKL) bone markers were measured by real time PCR (RT-PCR), serum calcitonin, interleukin-6 (IL-6), insulin, glucose, total cholesterol (TC), total triglycride (TG) were measured, HOMA-IR and BMI were calculated, bone histopathology was also done.

Results: In both normal and obese groups, obestatin caused significant decrease in RANKL, significant increase in osteopetrogenin, OPG/RANKL ratio, osteocalcin expression and serum calcitonin in comparison to their control, in subgroup $\mathrm{Ib}$ (obestatin treated normal group), there was significan decrease in BMI, however, there was non-significant change in serum glucose, insulin levels, HOMA-IR index, TC, TG, IL 6 levels in comparison to subgroup Ia. While, in subgroup $\mathrm{IIb}$ (obestatin treated obese group), there was a significant decrease in BMI, serum glucose, TG, TC, serum insulin levels, HOMA-IR index and IL 6 levels in comparison to subgroup IIa. In bone histopathology, subgroup Ib showing slight increase in bone trabeculae thickness in comparison to the control and subgroup IIa showed thin atrophic bone trabeculae with wide marrow spaces. While, subgroup IIb showed increased bone trabeculae thickness in comparison to the later.

Conclusion: Obestatin has anabolic effect on bone in normal and obese rats, which it can be used in regime diet

Correspondence to: Dr. Reham H. Ibrahim,

E-Mail: phisiology lover 4@yahoo.com induced weight loss, as it prevent the decrease of bone mass that accompany weight loss.

Key Words: Obestatin - Bone turnover - Osteocalcin Osteoprotegerin - RANKL.

\section{Introduction}

IT is interesting that adequate nutrient intake and normal gastrointestinal function are critical to bone health, which can be under constant repair and remodeling. Gut hormones may integrate a connection between food intake and bone turnover, this help in the management of the secondary causes of bone diseases associated with nutritional disturbance [1]

Obestatin (OBST) is a 23-amino-acid, peptide hormone that is mainly produced in the gastrointestinal tract and is derived from the posttranslational cleavage of the same peptide precursor of ghrelin [2] . OBST has been shown to regulate metabolic function at the central and the peripheral levels, which includes regulation of food intake and pancreatic, adipocyte, and cardiac function as well as cell proliferation [2-5]. It has been reported to bind to and activate the orphan $\mathrm{G}$ protein-coupled receptor-39 (GPR39), as well as the glucagon-like peptide-1 receptor (GLP1R) and growth hormone secretagogue receptor (GHSR) [2,6,7] .

This protein and its receptors are expressed on osteoblastic cell lines in different stages of maturity [8]. Moreover, in osteoblastic cell culture, there was increase in bone turnover markers (BTMs) production on exposure to OBST, with increased cell viability [1,9], these data reinforce the hypothesis that bone function might be under the influence of OBST released in response to changes in dietary intake $[\mathbf{1 , 9}]$.

It is interesting that obesity have adverse effects on bone health, as there is a negative associations 
between excess fat and bone mineral density (BMD), bone geometry and bone strength $[10,11]$ OBST appears to play an important role with clear potential relevance to obesity, as it prevent lipolysis and acts similarly to insulin, reduced insulin resistance and reduced inflammation in metabolic tissue [6].

The aim of this study is to determine the effect of OBST administration on bone metabolism in normal and high fat diet induced obese rats.

\section{Material and Methods}

In the period from 15 th February to 13 th July 2018, the study was performed in the animal house of Faculty of Medicine, Zagazig University and involved 32 healthy adult male albino rats of local strain weighting $(193 \pm 9.14 \mathrm{gm})$. All animals received care in compliance with the animal care guidelines and ethical regulations in accordance with the guide for the care and use of laboratory animals according to Institute of Laboratory Animal Resources, [12], the animals were housed in plastic cages under controlled hygienic conditions with an ambient temperature $\left(22 \pm 2^{\circ} \mathrm{C}\right)$ and normal light/ dark cycles with free access to food and water throughout the period of the study. After acclimation for one week, the rats were divided into 2 major equal groups:

Group I: Rats were fed on standard chow diet (5\% of energy derived from fat, $18 \%$ from proteins, and $77 \%$ from carbohydrates; $3.3 \mathrm{kcal} / \mathrm{g}$ ), then it divided into two subgroups $(\mathrm{n}=8) /$ each. Subgroup (Ia) (the normal control group): Each rat received intraperotonial (ip) injection of $100 \mathrm{ml}$ of saline "NaCl $0.9 \% "$ daily for 30 consecutive days. Subgroup (Ib) (OBST-treated normal group): Each rat received ip daily dose of obestatin $(1 \mathrm{nmol} / 100 \mathrm{gm}$ BW dissolved in $100 \mathrm{ml}$ saline) (Sigma Aldrich Co.-USA) for 30 consecutive days [13]

Group II: Rats were fed high fat diet (HFD) (Faculty of Agriculture, Zagazig University) (60\% fat, $21 \%$ carbohydrate, $18 \%$ protein and 5.1 calories/g) for 10 weeks to induce obesity [14], then it divided into two subgroups $(\mathrm{n}=8) / \mathrm{each}$.

Subgroup (II a) (the obese control group): Each rat received ip injection of $100 \mathrm{ml}$ of saline $\mathrm{NaCl}$ $0.9 \%$ " daily for 30 consecutive days. Subgroup (II b) (OBST-treated obese group): Each rat received ip daily dose of obestatin $(1 \mathrm{nmol} / 100 \mathrm{gm}$ BW dissolved in $100 \mathrm{ml}$ saline) (Sigma Aldrich Co.-USA) for 30 consecutive days [13].

Experimental design: 24 hours after the last injection of OBST, blood samples were collected from retro-orbital venous plexus and serum was separated by centrifugation of clotted blood at 3000 rpm for 20 minutes. The serum was kept deep frozen at $\left(-80^{\circ} \mathrm{C}\right)$ until biochemical serum analysis. Afterward, the animals were stunned and killed by a sharp blow to the head; the tibiae were extracted and quick-frozen at $\left(-70^{\circ} \mathrm{C}\right)$ until total RNA isolation.

Then the femur was removed from each rat, cleaned of adhering soft tissue, fixed and placed in $10 \%$ formalin solution for bone histopathology.

Quantitative analysis of gene expression of RANKL and Osteocalcin by real time PCR: According to krasemann et al., [15].

Total RNA extraction: Quick-frozen tibia were transported from $-70^{\circ} \mathrm{C}$ storage to liquid nitrogen until it was divided into two equal portions by diagonal pliers, one portion was individually powdered with a cold steel mortar and pestle, total RNA was extracted from tissue homogenate using SV Total RNA Isolation System (Promega, Madison, WI, USA) according to manufacturer's instruction. The RNA concentrations and purity were measured with an ultraviolet spectrophotometer.

\section{Complementary DNA (cDNA) synthesis}

The cDNA was synthesized from 1 RNA using SuperScript III First-Strand Synthesis System as described in the manufacturer's protocol (\#K1621, Fermentas, Waltham, MA, USA). In brief, 1 total RNA was mixed with 50 M oligo (dT) 20, 50ng/ Lrmam primers, and 10 $\mathrm{mM}$ dNTP mix in a total volume of 10 the mixture was incubated at $56^{\circ} \mathrm{C}$ for $5 \mathrm{~min}$, and then placed on ice for $3 \mathrm{~min}$. The reverse transcriptase master mix containing 2 of $25 \mathrm{mM} \mathrm{MgCl} 2,2 \mathrm{Co}$ SuperScript ${ }^{\circledR}$ III RT (200 U/ L) as added to the mixture and was incubated at $25^{\circ} \mathrm{C}$ for $10 \mathrm{~min}$ followed by $50 \mathrm{~min}$ at $50^{\circ} \mathrm{C}$.

\section{Real-time quantitative PCR:}

Real-time PCR amplification and analysis were performed using an Applied Biosystem with software version 3.1 (StepOneTM, USA). The reaction contained SYBR Green Master Mix (Applied Biosystems), gene-specific primer pairs which were shown in Table (1) and were designed with Gene Runner Software (Hasting Software, Inc., Hasting, NY) from RNA sequences from the gene bank. All primer sets had a calculated annealing temperature of $60^{\circ}$. Quantitative RT-PCR was performed in a 25- rection volume consisting of $2 \mathrm{X}$ SYBR Green PCR Master Mix (Applied Biosystems), 
900nM of each primer and 2 Lof DNA. Amplification conditions were: $2 \mathrm{~min}$ at $50^{\circ}, 10 \mathrm{~min}$ at $95^{\circ}$ and 40 cycles of denaturation for $15 \mathrm{~s}$ and annealing/ extension at $60^{\circ}$ for $10 \mathrm{~min}$. Data from real-time assays were calculated using the $\mathrm{v} 1.7$ sequence detection software from PE Biosystems (Foster City, CA). Relative expression of studied gene mRNA was calculated using the comparative $\mathrm{Ct}$ method. All values were normalized to beta actin which was used as the control housekeeping gene and reported as fold change over background levels detected in the examined groups.

- The primer sequence of the studied gene.

\begin{tabular}{lc}
\hline & \multicolumn{1}{c}{ Primer sequence } \\
\hline RANKL & - Forward primer: 5'-GAGACTACGGCA \\
& AGTA-3' \\
& - Reverse: 5'-CCTCCAACGTTTATGG-3' \\
Osteopro- & - Forward primer: 5'-TGGCACACAGTGA \\
tegerin & TGAATGCG-' \\
(OPG) & - Reverse: 5'-GCTGGAAAGTTTGCTCT \\
& TGCG-3' \\
& - Forward: 5'-TGGAGCTCGAATTCTGC \\
Osteocalcin & TTG-3' \\
& - Reverse: 5'-CATCAAGATGCGGAGC \\
& TGCT-3' \\
& - Forward primer: 5'-GGTCGGTGTGAAC \\
Beta actin & GGATTTGG -3 \\
& - Reverse primer: 5'-ATGTAGGCCATGAG \\
& GTCCACC-3 \\
\hline
\end{tabular}

Anthropometric measures: Measuring body weight: The animal was put in closed plastic container and weighed one day before the experiment and at the last day. The results were recorded for each labeled rat. Measuring rat length: By metal ruler, nose to anus length was measured. Calculating BMI index: Body mass index (BMI) equals body weight $(\mathrm{g}) /$ length $2\left(\mathrm{~cm}^{2}\right)$, this index can be used as an indicator of obesity where the cut off value of obesity BMI is more than $0.68 \mathrm{~g} / \mathrm{cm}^{2}[16]$.

Serum analysis:

Serum calcitonin: By using rat calcitonin (CT) ELISA kits Cat. No. KT-8860 according to Zhou et al., [17].

Serum glucose level: According to Tietz et al., [18] using glucose enzymatic (GOD-PAP)-liqui zyme Kits (Biotechnology, Egypt).

Serum insulin level: By a solid phase enzyme amplified sensitivity immunoassay according to Temple et al., [19] using KAP1251-INS-EASIA (Enzyme Amplified Sensitivity Immunoassay) Kits (BioSource Europe S.A., Belgium). HOMA-IR:
Was assessed by homeostasis model assessment equation where [HOMA-IR=insulin $(\mathrm{U} / \mathbf{L} \mathbf{L}) \mathrm{x}$ glucose $(\mathrm{mg} / \mathrm{dL}) / 405]$ [20, 21] . Serum total cholesterol (TC) level: According to Tietz et al., [18] using rat cholesterol enzyme-linked immunosorbent assay kit, (BioSource Europe S.A.-Rue de l'Industrie, 8-B- 1400 Nivelles-Belgium). Serum triglycerides (TG) level: Using rat triglycerides enzyme-linked immunesorbent assay kit, (BioSource Europe S.A.-Rue de l'Industrie, 8-C- 1150 NivellesBelgium) according to Fossati and Prencipe [22] . Serum IL6: By using a double-antibody sandwich ELISA rat IL-6 kits according to Song et al., [23].

\section{Bone histopathological sections:}

The femur was removed from each rat, cleaned of adhering soft tissue, fixed and placed in $10 \%$ formalin solution for one day [24]. After proper fixation of the specimens, tissues were processed in ascending grades of alcohol, cleaned in xylol and embedded in paraffin blocks. 4 microns sections were cut on a standard rotatory microtome. Serial sections were stained by heamatoxylin and eosin stain (H\&E) and observed for histopathological changes as described by [25] .

Statistical analysis: The data obtained in the present study were expressed as mean \pm SD for quantitative variables and statistically analyzed by using SPSS program (version 18 for windows) (SPSS Inc. Chicago, IL, USA). One way analysis of variance (ANOVA) was done followed by LSD test to compare means of the different groups. $p$ value $<0.05$ was considered statistically significant.

\section{Results}

Effect of OBST on anthropometric and serum metabolic parameters: As shown in Table (1), subgroup Ib (OBST treated normal group): There was significant decrease in BMI $(p<0.05)$, however, there was non-significant change in serum glucose, insulin levels, HOMA-IR, TC, TG, IL6 levels in comparison to subgroup Ia (normal control group).

In subgroup IIa: (Obese control group), there was a significant increase in BMI, serum glucose, insulin levels, HOMA-IR index, TC, TG, IL6 levels $(p<0.001)$ in comparison to both subgroup Ia and subgroup Ib.

In subgroup IIb: (OBST treated obese group), there was a significant decrease in BMI, serum glucose, TC, TG $(p<0.001)$, insulin, HOMA-IR index and IL6 levels $(p<0.01)$ in comparison to subgroup IIa (obese control group), however, there was significant increase in BMI $(p<0.01)$ in comparison to subgroup $\mathrm{Ib}$, in addition, there was 
significant increase in serum glucose, TG $(p<0.001)$, TC and HOMA-IR index $(p<0.05)$ in comparison to subgroup Ia and Ib.

Effect of OBST administration on gene expression of RANKL, Osteopetrogenin and Osteocalcin by real time $P C$ : As shown in Table (2), subgroup $\mathrm{Ib}$, there was a significant decrease in RANKL $(p<0.05)$, however, there was significant increase in both Osteopetrogenin, OPG/RANKL ratio and Osteocalcin $(p<0.05)$ in comparison to subgroup Ia. In subgroup IIa, there was a significant increase in RANKL $(p<0.05)$, however, there was significant decrease in Osteopetrogenin, OPG/RANKL ratio and Osteocalcin $(p<0.05)$ in comparison to both subgroup Ia and subgroup Ib.

In subgroup IIb, there was a significant decrease in RANKL $(p<0.05)$ in comparison to subgroup II a, while significant increase in RANKL $(p<0.05)$ in comparison to subgroup Ib. In addition, there was significant increase in Osteopetrogenin, OPG/ RANKL ratio and Osteocalcin $(p<0.05)$ in comparison to subgroup IIa, while significant decrease in the same parameters $(p<0.05)$ in comparison to subgroup Ib.

Effect of OBST on serum level of Calcitonin: As presented in Table (3), subgroup Ib, there was a significant increase in serum calcitonin $(p<0.05)$ in comparison to subgroup Ia. In subgroup IIa, there was significant decrease in calcitonin $(p<0.05)$ in comparison to subgroup Ib, In subgroup IIb, there was significant increase in calcitonin $(p<0.05)$ in comparison to subgroup IIa.

\section{Histopathological examination:}

The photomicrographs of normal control rats showing normal thick bone trabeculae with bone marrow spaces in between (Fig. 1), obestatin treated normal rats showing slight increase in bone trabeculae thickness in comparison to normal control rats (Fig. 2). Obese control rats showed thin atrophic bone trabeculae with wide marrow spaces (Fig. 3). OBST treated obese rats showed increased bone trabeculae thickness in comparison to obese control rats (Fig. 4).

Table (1): Effect of OBST on anthropometric and serum metabolic parameters in all groups.

\begin{tabular}{|c|c|c|c|c|}
\hline $\begin{array}{l}\text { Groups } \\
\text { Parameters } \\
\end{array}$ & $\begin{array}{c}\text { Subgroup Ia } \\
\text { (normal control) }\end{array}$ & $\begin{array}{l}\text { Subgroup Ib } \\
\text { (OBST treated) }\end{array}$ & $\begin{array}{l}\text { Subgroup IIa } \\
\text { (obese control) }\end{array}$ & $\begin{array}{l}\text { Subgroup IIb } \\
\text { (OBST treated) }\end{array}$ \\
\hline BMI (g/cm $\left.{ }^{2}\right)$ & $0.58 \pm 0.06$ & $0.49 \pm 0.07^{\mathrm{a}^{*}}$ & $0.81 \pm 0.04^{\mathbf{a b}} \mathbf{b}^{* * * *}$ & $0.61 \pm 0.07^{\mathbf{b}^{* *} \mathbf{c}^{* * *}}$ \\
\hline Glucose (mg/dl) & $93 \pm 6.6$ & $91 \pm 3.1$ & $188 \pm 2.5^{\mathbf{a b}^{* * *}}$ & $130 \pm 4.2$ abc $* * *$ \\
\hline Insulin (IUml) & $11.93 \pm 1.77$ & $11.33 \pm 6.4$ & $21.33 \pm 0.91 \mathbf{a b}^{* * * *}$ & $13.6 \pm 0.2^{c^{* * *}}$ \\
\hline HOMA-IR & $2.7 \pm 0.07$ & $2.54 \pm 1.03$ & $9.9 \pm 0.25^{\mathbf{a b}} \mathbf{b}^{* * * *}$ & $4.36 \pm 0.7 \mathbf{a b}^{*} \mathrm{c}^{* *}$ \\
\hline $\mathrm{TC}(\mathrm{mg} / \mathrm{dl})$ & $89.27 \pm 10.6$ & $84 \pm 8.2$ & $152 \pm 13.23^{\mathbf{a b}^{* * * *}}$ & $102.5 \pm 11.08 \mathbf{a b}^{*} \mathbf{c}^{* * * *}$ \\
\hline TG (mg/dl) & $65.50 \pm 15.3$ & $67 \pm 11.6$ & $140.83 \pm 11.59^{\mathbf{a b}}$ & $95.01 \pm 8.91 \mathbf{a b c}^{* * * *}$ \\
\hline IL6 (pg/ml) & $46.9 \pm 13$ & $43.2 \pm 10$ & $69 \pm 12^{\mathbf{a b}^{* * \ldots \times k}}$ & $51 \pm 9 \mathrm{c}^{* * *}$ \\
\hline
\end{tabular}

(a)=Significant vs. group Ia.

(b) =Significant vs. group Ib.

(c) $=$ Significant vs. group IIa.

Table (2): Effect of OBST on gene expression of RANKL, Osteopetrogenin and Osteocalcin by real time PCR in all groups.

\begin{tabular}{lllll}
\hline Groups & $\begin{array}{c}\text { Subgroup Ia } \\
\text { (normal control) }\end{array}$ & $\begin{array}{c}\text { Subgroup Ib } \\
\text { (OBST treated) }\end{array}$ & $\begin{array}{c}\text { Subgroup IIa } \\
\text { (obese control) }\end{array}$ & $\begin{array}{c}\text { Subgroup IIb } \\
\text { (OBST treated) }\end{array}$ \\
\hline RANKL & $0.95 \pm 0.18$ & $0.88 \pm 0.22^{\mathbf{a}^{*}}$ & $1.7 \pm 0.46^{\mathbf{a b}}{ }^{*}$ & $0.97 \pm 0.33 \mathbf{b c}^{*}$ \\
Osteopetrogenin & $0.9 \pm 0.16$ & $1.4 \pm 0.52^{\mathbf{a}^{*}}$ & $0.65 \pm 0.17^{\mathbf{a b}}$ & $0.95 \pm 0.22^{*} \mathbf{b c}^{*}$ \\
OPG/RANKL Ratio & $0.94 \pm 0.0 .08$ & $1.5 \pm 0.12^{\mathbf{a}^{*}}$ & $0.38 \pm 0.26^{\mathbf{a b}}$ & $0.97 \pm 0.1 \mathbf{b c}^{*}$ \\
Osteocalcin & $1.1 \pm 0.56$ & $1.6 \pm 0.43^{\mathbf{a}^{*}}$ & $0.45 \pm 0.18^{\mathbf{a b}}$ & $1.2 \pm 0.25^{*} \mathbf{b c}^{*}$ \\
\hline
\end{tabular}

(a)=Significant vs. group Ia. $\quad$ (b)=Significant vs. group Ib. $\quad$ (c)=Significant vs. group IIa.

Table (3): Effect of OBST on serum level of Calcitonin (ng/dl) in all groups.

\begin{tabular}{lcccc}
\hline \multicolumn{1}{c}{ Groups } & $\begin{array}{c}\text { Subgroup Ia } \\
\text { (normal control) }\end{array}$ & $\begin{array}{c}\text { Subgroup Ib } \\
\text { (OBST treated) }\end{array}$ & $\begin{array}{c}\text { Subgroup IIa } \\
\text { (obese control) }\end{array}$ & $\begin{array}{c}\text { Subgroup IIb } \\
\text { (OBST treated) }\end{array}$ \\
\hline Carameters & $42 \pm 3.5$ & $49 \pm 2.8^{\mathbf{a}^{*}}$ & $36 \pm 2.2^{\mathbf{b}^{*}}$ & $45 \pm 3 . \mathbf{c}^{*}$ \\
\hline (a)=Significant vs. group Ia. & (b) $=$ Significant vs. group Ib. & (c)=Significant vs. group IIa.
\end{tabular}

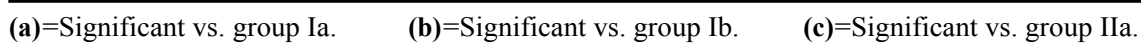




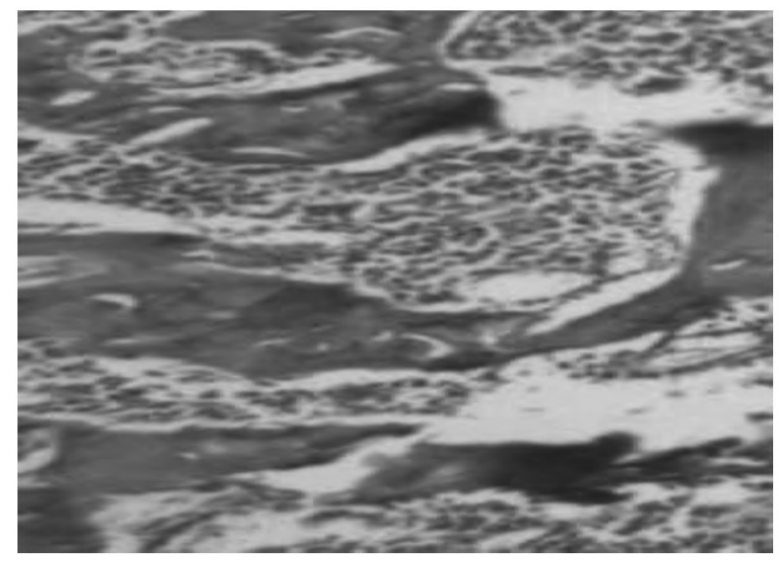

Fig. (1): A photomicrograph of a section from femur bone of normal control rats showing normal thick bone trabeculae with bone marrow spaces $(\mathrm{BM})$ in between $(\mathrm{H}$ \& E stain, $x$ 400).

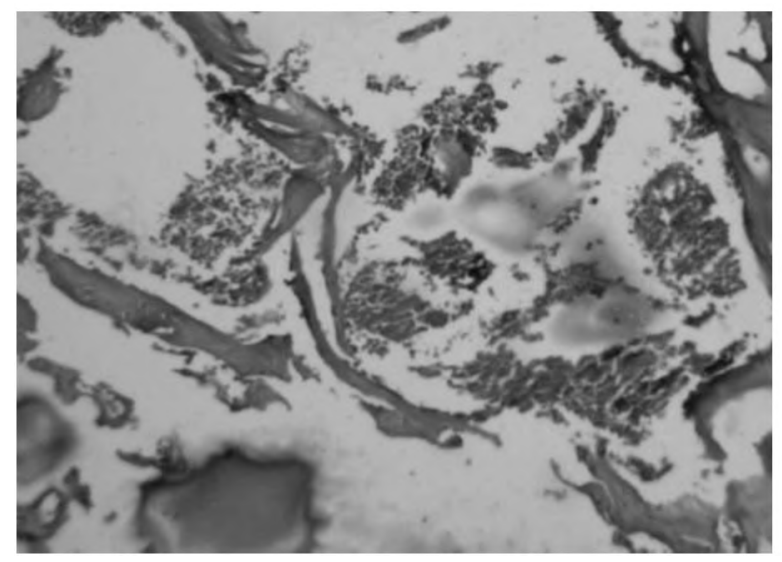

Fig. (3): A photomicrograph of a section from femur bone of obese control rats showing thin atrophic bone trabeculae with wide BM spaces in between (H \& E stain $\mathrm{x}$ 400).

\section{Discussion}

The present study demonstrated bone anabolic effect of OBST in both normal and HFD induced obese rats, OBST modulated bone metabolism by changes in bone turnover markers (BTMs), which are either by-products of collagen formation or breakdown, or cell proteins that reflect osteoclastic or osteoblastic activity, changes in BTMs reflect alterations in bone metabolism [26].

It is worth saying that, chronic OBST administration for 1 month in normal rats, increased bone trabecular thickness indicated in bone histopathology, in addition, it increased bone osteocalcin gene expression, which is the most abundant non-collagenous protein in bone [27]. Osteocalcin is produced by osteoblasts and is widely accepted as a marker of bone osteoblastic activity, it play an important role in bone formation, importantly, in the differentiation of osteoblast progenitor cells and in bone matrix synthesis and mineralization process $[27,28]$

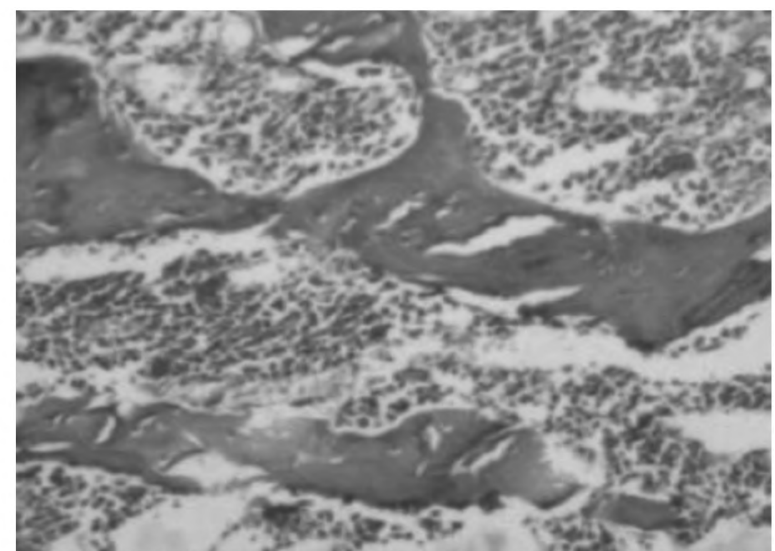

Fig. (2): A photomicrograph of a section from femur bone of OBST treated normal rats showing slight increase in bone trabeculae thickness.

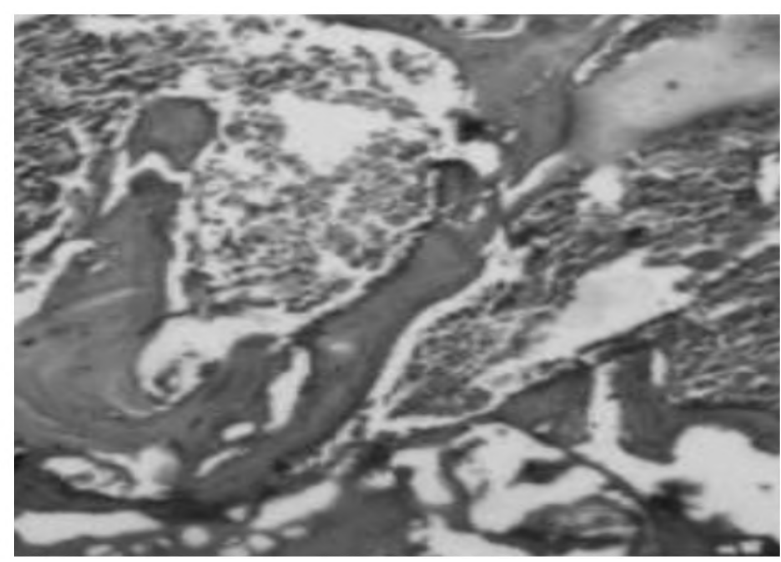

Fig. (4): A photomicrograph of a section from femur bone of OBST treated obese rats showing increased bone trabeculae thickness (H \& E stain, x400)

One of the key regulators of bone resorption is the RANK/RANK ligand system [2] . Receptor activator nuclear factor $\kappa \mathrm{B}$ (RANK) is a receptor expressed on the cell membrane of osteoclast precursors and mature osteoclasts, and its activation stimulates osteoclast differentiation and activity [3]. RANK ligand (RANKL) is secreted by stromal cells or osteoblasts and is the major paracrine factor in activating the RANK system in the osteoclast bone remodelling unit that increase bone resorption [31]. Many of the important regulators of bone resorption may act through the alteration of the relative amounts of RANKL secreted by osteoblasts [32-34].

Osteoprotegerin (OPG), also known as osteoclastogenesis inhibitory factor [35], it functions as a trap receptor by binding RANKL on osteoblast/ stromal cells, it blocks the RANKL-RANK interaction between osteoblast/stromal cells and osteoclast precursors, so OPG prevents RANK- activa- 
tion [36]. As a result, OPG can reduce the production of osteoclasts by inhibiting the differentiation of osteoclast precursors into osteoclasts and also regulates the resorption of osteoclasts [37]. In the current study, the chronic OBST adminstration decrease RANKL and increase Osteoprotegerin gene expression accompanied by increased OPG/ RANKL ratio.

Moreover, our results showed that OBST increased serum calcitonin, this may be through its action on GLP-1R [6], since GLP-1R is expressed in thyroid $\mathrm{C}$ cells [38]. One study documents that GLP-1R agonists cause calcitonin release in mice via a GLP-1R-dependent mechanism [39]. Calcitonin inhibits osteoclastogenesis [40], it is a known inhibitor of bone resorption, it can act directly on osteoblasts by increasing proliferation, and inhibiting RANKL mRNA expression [41].

The current study indicates that HFD induced obesity in subgroup IIa since the rise in TC and TG was associated with significant increase in BMI. Moreover, our results revealed significant increase in serum glucose, insulin, level of HOMAIR in the same group. These results are in line with those of Sjoholm and Nystrom [42] and Eisinger, et al., [43] who noticed that HFD can cause development of many features of metabolic syndrome as disturbance in lipid metabolism and IR.

In addition, the results of this study indicate that obesity cause bone resorption as proved histopathological in obese group, showed thin atrophic bone trabeculae with wide marrow spaces, furthermore, real time PCR showed increased femur bone RANKL, decreased OPG and osteocalcin gene expression, with decreased OPG/RANKL ratio, these results were supported by Halade et al., [44] who reported that OPG secretion decreased and RANKL expression increased in osteoblasts stimulated with adipocyte-secreted factors.

Moreover, the current study reported increased IL6 level in the obese group, as obesity is considered a low grade pro-inflammatory state, associated with greater concentrations of pro-inflammatory cytokines [45], The secretion of RANKL was regulated by cytokines as interleukin-1 (IL-1) [46], tumor necrosis factor [47] and IL-6 [48], inflammatory cytokines are positively associated with osteoclastogenesis as they upregulated RANKL mRNA expression in osteoblasts, consistent with osteoclast differentiation [49], enhance osteoclast activity and bone resorption [50,51]. As a result, inflammatory cytokines are negatively associated with bone strength [5] and positively associated with fracture risk [53].
Furthermore, obesity may decrease bone formation (osteoblastogenesis) while increasing adipogenesis because adipocyte and osteoblasts are derived from a common multi-potential mesenchymal stem cell [54]. Activation of peroxisome proliferator-activated receptor gamma (PPAR y) decreased osteoblast differentiation, bone mineral density and trabecular bone mass while increasing adipocytes differentiation and bone marrow adipose tissue volume $[\mathbf{5 5 , 5 6 ]}$.

In addition, the increased IR reported in obese group may contribute to increased bone resorption, as insulin is a potential regulator of bone growth, it may act as an anabolic agent in bone and preserve bone mass in humans [57], insulin stimulates bone formation and osteocalcin secretion upon activation of insulin receptor signaling [58]. In addition, it decrease markers of bone resorption, this suggests that insulin may act as an anabolic agent for bone metabolism, by shifting the balance in the favor of bone formation [59].

In OBST treated obese group, there was increased osteocalcin and OPG gene expression, decreased RANKL expression, increased serum level of calcitonin were reported, in addition, bone histopathology showed increased bone trabecular thickness in comparison to obese control group.

OBST appears to play an important role with clear potential relevance to obesity and diabetes. Indeed, it is interesting that, OBST levels are reduced in obesity suggesting that it may be a nutritional marker reflecting body adiposity and IR $[60,61]$

In the current study, OBST decreased factors that help bone resorption in obesity, as it decreased serum IL6, this result was in line with those of Zhang et al., [62] and supported by what reported by Ozge et al., [63] that OBST suppressed PMNL infiltration, inhibiting reactive oxygen radical generation and proinflammatory cytokine production, and provoking the synthesis of anti-inflammatory cytokines during the progression of both acute and chronic colitis.

Furthermore, OBST reduced HOMA-IR, our result are in line with those of Granata et al., [6], in addition, it inhibited the HFD-induced reduction of pancreatic islet area possibly because of its antiapoptoic and survival effects in $\beta$-cells, and strongly stimulated glucose-induced insulin secretion in pancreatic islets. The results of the present study showed a significant reduction in BMI, serum TG and TC in OBST-treated obese rats, Granata et al., [6] support this result as they reported that 
in OBST-treated HFD fed mice, epididymal fat showed increased glucose uptake, increased number of small and likely insulin-sensitive adipocytes, and reduced lipolysis, so this protein appear to decrease risk factors that predispose to obesity and impaired bone quality.

Another mechanisms that may contribute to anabolic effect of OBST in normal and obese rats, it was reported that OBST can induce testosterone secretion in normal [13] and obese rats [64]. Low testosterone levels in boys have been associated with lower bone density [65].

Moreover, anabolic role of OBST on bone may be due to its enhancing effect on the expression of vascular endothelial growth factor (VEGF) and its receptor isoform VEGFR2 in muscle [66]. VEGF is able to stimulate various aspects of bone development, including chondrocyte differentiation, osteoblast differentiation [67], in addition, it promote ossification by inducing neovascularisation and maximum levels of VEGF expression precede the maximum level of new bone formation in the condyle. This indicates a close correlation between vascularisation and bone formation [68,69]. Moreover, gene therapy explored in the condylar area, has shown that recombinant adeno-associated virusmediated VEGF is an efficient delivery system to induce mandibular condylar growth [70].

Furthermore, OBST stimulate leptin secretion [71], leptin is an adipocyte-derived hormone that acts on receptors in the hypothalamus, decreasing food intake and increasing energy expenditure [72], Central infusions of leptin in leptin-deficient receptor mice actually increase cortical bone formation and total bone mass, [73] however, leptin also has important peripheral and direct effects on osteoblasts and bone-derived mesenchymal stem (stromal) cells (BMSCs), as leptin treatment of leptin-sensitive BMSCs increases the expression of bone morphogenetic protein 2 (BMP-2) [74,75] It was confirmed that leptin can promote osteoblast mineralization and down-regulate the RANKL mRNA expression [76].

Conclusion: In the present study, an apparent stimulation of bone remodeling favoring bone formation by obestatin in both normal and obese rats, the present data support antiresorptive character of obestatin and suggest that obestatin might be useful as a beneficial agent for improving the deficient bone formation and bone structure associated with obesity.

\section{Acknowledgment:}

To Prof/Kamal El-Kashishy, Pathology Department, Faculty of Medicine, Zagazig University, for performing the histopathological studies and to prof/Somiaa Hassan, Biochemistry Department, Faculty of Medicine, Zagazig University, for perform the laboratory tests.

\section{References}

1- PACHECO-PANTOJA E., RANGANATH L. and WILSON P.: Effects of five gut hormones on osteoblastic-like cell lines. Endo. Abs., 19: 4, 2009.

2- ZHANG J.V., JAHR H., LUO C.W. and KLEIN C.: Obestatin induction of early response gene expression in gastrointestinal and adipose tissues and the mediatory role of G protein-coupled receptor, GPR39. Mol. Endocrinol., 22: 1464-1475, 2008.

3- HASSOUNA R., ZIZZARI P. and TOLLE V.: The ghrelin/ obestatin balance in the physiological and pathological control of growth hormone secretion, body composition and food intake. J. Neuroendocrinol., 22: 793-804, 2010.

4- SLUPECKA M., WOLIN'SKI J., HERMAN A.P., OCHNIEWICZ P. and KORNACKA M.K.: Biological role of obestatin in physiology and pathophysiology. Med. Wieku. Rozwoj., 16: 47-52, 2012.

5- ABOU FARD G.M., MADI N.M. and ABO ZADE A.A.: Circulating obestatin level in diabetic and obese rats. Tanta Medical Journal, 42 (1): 1-5, 2014.

6- GRANATA R., GALLO D., LUQUE R.M., BARAGLI A. and SCARLATTI F.: Obestatin regulates adipocyte function and protects against diet-induced insulin resistance and inflammation. FASEB, 26: 3393-3411, 2012.

7- PRADHAN G., WU C.S. and LEE J.H.: Obestatin stimulates glucose-induced insulin secretion through ghrelin receptor GHS-R. Sci. Rep., 7 (1): 979, 2017.

8- PACHECO-PANTOJA E., WILSON P. and RANGANATH L.: Expression and function of gut hormone receptors in osteoblast cell lines. Endocrine Abstracts, 15: 18, 2008.

9- PACHECO-PANTOJA E.L., RANGANATH L.R. and GALLAGHER J.A.: Receptors and effects of gut hormones in three osteoblastic cell lines. BMC Physiol., 11: 12, 2011.

10- DIMITRI P., WALES J.K. and BISHOP N.: Adipokines, bone-derived factors and bone turnover in obese children; evidence for altered fat-bone signalling resulting in reduced bone mass. Bone, 48: 189-96, 2011.

11- LORINCZ C., REIMER R.A., BOYD S.K. and ZERNICKE R.F.: High-fat, sucrose diet impairs geometrical and mechanical properties of cortical bone in mice. Br. J. Nutr., 103 (9): 1302-1308, 2010.

12- Institute of Laboratory Animal Resources, Commission on life sciences and National research council: Guide for the care and use of laboratory animals, 8 th Edition. Pbl: National academy press, Washington D.C., pp. 21-55, 1996. 
13- JAHAN S., SIDRAT T., AHMED S., WAZIR H. and ULLAH K.: Effect of obestatin on morphometry of testes and testosterone secretion in male rats. African Journal of Biotechnology, 10 (39): 7717-22, 2011.

14-FRAULOB J.C., OGG-DIAMANTINO R., FERNANDESSANTOS C. and AGUILA M.B.: A Mouse Model of Metabolic Syndrome: Insulin Resistance, Fatty Liver and Non-Alcoholic Fatty Pancreas Disease (NAFPD) in C57BL/6 Mice Fed a High Fat Diet. J. Clin. Biochem. Nutr., 46 (3): 212-23, 2010.

15- KRASEMANN S., MEARINI G., KRÄMER E. and WAGENFÜHR K.: BSE-associated Prion-Amyloid Cardiomyopathy in Primates. Emerg. Infect. Dis., 19 (6): 985-988, 2013.

16-NOVELLI E., DINIZ Y., GALHARDI C., EBAID G. and RODRIGUES H.: Anthropometrical parameters and markers of obesity in rats. Laboratory Animals, 41: 111-119, 2007.

17- ZHOU Z., NING C. and YANG G.: The effects of ZJXG decoction on the serum CT levels and the expressions of CTR and Cbfa1 in callus of femur fracture rats. Biomed. Res., 27 (3), 2016.

18- TIETZ N.W., COOK T. and MCNIVEN M.A.: Clinical Guide to Laboratory Tests; W.B. Saunders: Philadelphia, pp. 509-512, 1995.

19- TEMPLE R.C., CLARK P.M. and HALES C.N.: Measurement of insulin secretion in type 2 diabetes: Problems and pitfalls. Diab. Med., 9: 503-551, 1992.

20- MATTHEWS D.R., HOSKER J.P., RUDENSKI A.S. and NAYLOR B.A.: Homeostasis model assessment: insulin resistance and beta-cell function from fasting plasma glucose and insulin concentrations in man. Diabetologia, 28: 412-419, 1985.

21- SUN G., BISHOP J., KHALILI S. and VASDEV S.: Serum visfatin concentrations are positively correlated withserum triacylglycerols and down-regulated by overfeeding in healthy young men. Am. J. Clin. Nutr., 85: 399-404, 2007.

22- FOSSATI P. and PRENCIPE L.: Serum Triglycerides Determined Colorimetrically with an Enzyme that Produces Hydrogen Peroxide. Clin. Chem., 28: 2077-2080, 1982.

23- SONG C., DINAN T. and LEONARD B.E.: Changes in immuno-globulin complement and acute phase protein levels in the depressed patients and normal controls. J. Affect Disord., 30: 283-288, 1994.

24- RAAB J.K., ALAN S.T. and DRURY W: Histological methods for bone, 5 th ed., Oxford University Press, New York, Toronto, pp. 185, 1991.

25- BANCROFT D. and COOK J.: Organic chelating agents for decalciflcation of bone. Stain Technology, 28: 285, 1984.

26- NAYLOR K. and EASTELL R.: Bone turnover markers: use in osteoporosis. Nat. Rev. Rheumatol., 8: 379, 2012.

27- LIAN J.B. and STEIN G.S.: Runx2/Cbfa1: A multifunctional regulator of bone formation. Curr. Pharm. Des., 9: $2677-85,2003$.

28- RUMPLER M., VARGA F. and KLAUSHOFER K.: A novel cDNA transcript inversely regulated to osteocalcin in differentiating osteoblast-like cells. DNA. Cell. Biol., 21 (3): 189-97, 2002.

29- WALSH M.C. and CHOI Y.: Biology of the RANKLRANK-OPG system in immunity, bone, and beyond. Front. Immunol., 5: 511, 2014.

30- BOYCE B.F. and XING L.: Biology of RANK, RANKL, and osteoprotegerin. Arthritis Res. Ther., 9 (1): S1.10. 1186/ar2104, 2007.

31- XING L., SCHWARZ E.M. and BOYCE B.F.: Osteoclast precursors, RANKL/RANK, and immunology. Immunol. Rev., 208: 19-29, 2005.

32- TYROVOLA J.B., SPYROPOULOS M.N., MAKOU M. and PERREA D.: Root resorption and the OPG/RANKL/ RANK system: A mini review. J. Oral., Sci., 50: 367-376, 2008.

33- GOTO H., OSAKI M. and FUKUSHIMA T.: Human bone marrow adipocytes support dexamethasone-induced osteoclast differentiation and function through RANKL expression. Biomed. Res., 32: 37-44, 2011.

34- XU F., DU Y. and HANG S.: Adipocytes regulate the bone marrow microenvironment in a mouse model of obesity. Mol. Med. Rep., 1572: 823-828, 2013.

35- KEARNS A., KHOSLA S. and KOSTENUIK P.: Receptor activator of nuclear factor $\mathrm{kB}$ ligand and osteo-protegerin regulation of bone remodeling in health and disease. Endocr. Rev., 29: 155-192, 2008.

36- BOYCE B. and XING L.: Functions of RANKL/RANK/ OPG in bone modeling and remodeling. Arch. Biochem. Biophys, 473: 139-146, 2008.

37- ZAULI G., RIMONDI E. and SECCHIERO P.: Soluble TRAIL does not impair the anti-osteoclastic activity of osteoprotegerin. J. Cell. Mol. Med., 12: 1063-1065, 2008.

38- WASER B., BEETSCHEN K., PELLEGATA N.S. and REUBI J.C.: Incretin receptors in non-neoplastic and neoplastic thyroid $\mathrm{C}$ cells in rodents and humans: Relevance for incretin-based diabetes therapy. Neuroendocrinol., 94: 291-301, 2011.

39- MADSEN L.W., KNAUF J.A. and GOTFREDSEN C.: GLP-1 receptor agonists and the thyroid: C-cell effects in mice are mediated via the GLP-1 receptor and not associated with RET activation. Endocrinol., 153 (3): 1538-1547, 2012.

40- GRANHOLM S., LUNDBERG P. and HLERNER U.: Calcitonin inhibits osteoclast formation in mouse haematopoetic cells independently of transcriptional regulation by receptor activator of NF- $\mathrm{kB}$ and c-Fms. J. Endocrinol., 195: 415-427, 2007.

41- TIAN Q.X., HUANG G.Y., ZHOU J.L. and LIU Q.H.: Effects of calcitonin on osteoblast cell proliferation and OPG/RANKL expression: Experiment with mouse osteoblasts. Zhonghua. Yixue. Zazhi., 87: 1501-1505, 2007.

42- SJOHOLM A. and NYSTROM T.: Inflammation and the etiology of type 2 diabetes. Diab. Metabol. Res. Rev., 22: 4-10, 2006.

43- EISINGER K.; LIEBISCH G., SCHMITZ G. and ASLANIDIS C.: Lipidomic Analysis of Serum from High Fat Diet Induced Obese Mice. Int. J. Mol. Sci., 15 (2): 29913002, 2014. 
44- HALADE G.V., EL JAMALI A. and WILLIAMS P.J.: Obesity-mediated inflammatory microenvironment stimulates osteoclastogenesis and bone loss in mice. Exp. Gerontol., 46: 43-52. 2011.

45- GOMEZ R., LAGO F., GOMEZ-REINO J. and DIEGUEZ C.: Adipokines in the skeleton: influence on cartilage function and joint degenerative diseases. J. Mol. Endocrinol., 43 (1): 11-18, 2009.

46- YAO Z., XING L., QIN C. and SCHWARZ E.M.: Osteoclast precursor interaction with bone matrix induces osteoclast formation directly by an IL-1-mediated autocrine mechanism. J. Biol. Chem., 283 (15): 9917-9924, 2008.

47- YAMASHITA T., YAO Z., LI F. and ZHANG Q.: NFkappaB p50 and $\mathrm{p} 52$ regulate receptor activator of NFkappaB ligand (RANKL) and tumor necrosis factorinduced osteoclast precursor differentiation by activating c-Fos and NFATc1. J. Biol. Chem., 282: 18245-18253, 2007.

48- TAKAYANAGI H.: New developments in osteoimmunology. Nat. Rev. Rheumatol., 9: 684-689, 2012.

49- DING C., PARAMESWARAN V., UDAYAN R. and BURGESS J.: Circulating levels of inflammatory markers predict change in bone mineral density and resorption in older adults: A longitudinal study. J. Clin. Endocrinol. Metab., 93 (5): 1952-1958, 2008.

50- SCHETT G.: Effects of inflammatory and anti-inflammatory cytokines on the bone. Eur. J. Clin. Invest., 41 (12): 1361-1366, 2011.

51- PINO A.M., RIOS S., ASTUDILLO P. and FERNANDEZ M.: Concentration of adipogenic and proinflammatory cytokines in the bone marrow supernatant fluid of osteoporotic women. J. Bone. Miner. Res., 25 (3): 492-498, 2010.

52- ISHII S., CAULEY J.A., GREENDALE G.A. and CRANDALL C.J.: C-reactive protein, bone strength, and nineyear fracture risk: Data from the Study of Women's Health Across the Nation (SWAN). J. Bone. Miner. Res., 28 (7): 1688-1698, 2013.

53- BARBOUR K.E., BOUDREAU R., DANIELSON M.E. and YOUK A.O.: Inflammatory markers and the risk of hip fracture: The Women's Health Initiative. J. Bone. Miner. Res., 27 (5): 1167-1176, 2012.

54- LAZARENKO O.P., RZONCA S.O. and HOGUE W.R.: Rosiglitazone induces decreases in bone mass and strength that are reminiscent of aged bone. Endocrinol., 148: 26692680, 2007.

55- SHOCKLEY K.R., LAZARENKO O.P., CZERNIK P.J. and ROSEN C.J.: PPARy 2 nuclear receptor controls multiple regulatory pathways of osteoblast differentiation from marrow mesenchymal stem cells J. Cell. Biochem., 106: 232-246, 2009.

56- MARCIANO D.P., KURUVILLA D.S., BOREGOWDA S.V. and ASTEIAN A.: Pharmacological repression of PPARgamma promotes osteogenesis. Nat. Commun., 6: 7443, 2015.

57- HAMANN C., KIRSCHNER S., GUNTHER K.P. and HOFBAUER L.C.: Bone, sweet bone-osteoporotic fractures in diabetes mellitus. Nat. Rev. Endocrinol., 8: 297305, 2012.
58- FERRON M., WEI J., YOSHIZAWA T. and DEL FATTORE A.: Insulin signaling in osteoblasts integrates bone remodeling and energy metabolism. Cell, 142: 296-308, 2010.

59- IVASKA K.K., HELIÖVAARA M.K. and EBELING P.: The effects of acute hyperinsulinemia on bone metabolism. Endocr. Connect, 4 (3): 155-162, 2015.

60- GU P.Y., KANG D.M. and WANG W.D.: Relevance of Plasma Obestatin and Early Arteriosclerosis in Patients with Type 2 Diabetes Mellitus. J. Diab. Res., Article ID 563919, 2013.

61- WANG W.M., LI S.M., DU F.M. and ZHU Z.C.: Ghrelin and obestatin levels in hypertensive obese patients. J. Int. Med. Res., 42 (6): 1202-1208, 2014.

62- ZHANG Q., DONG X.W. and XIA J.Y.: Obestatin Plays Beneficial Role in Cardiomyocyte Injury Induced by Ischemia-Reperfusion In Vivo and In Vitro. Inter. Med. J. Exper. Clin. Res., 23: 2127-2136, 2017.

63- OZGE P., KUMRA L. and FERIHA E.: Anti-inflammatory Effect of Obestatin and Ghrelin in Dextran Sulfate SodiumInduced Colitis in Rats. J. Pediat. Gastroenterol. Nutr., 57 (2): 211-218, 2013.

64- IBRAHIM M.H., SELIM S.A. and ABD-ALALEEM D.I.: Effect of Obestatin on Gonadal Functions in High Fatfed Albino Rats. Basic. Sci. Med., 3 (3): 43-59, 2014.

65- MISRA M., NAYLOR K. and EASTELL R.: Bone turnover markers: Use in osteoporosis. Nat. Rev. Rheumatol., 8 (7): 379-389, 2012.

66- GURRIARÁN-RODRÍGUEZ U., SANTOS-ZAS I. and AL-MASSADI O.: The Obestatin/GPR39 System Is Upregulated by Muscle Injury and Functions as an Autocrine Regenerative System. J. Biological. Chem., 287 (45): 38379-3 83 89, 2012.

67- YANG Y.Q., TAN Y.Y. and WONG R.: The role of vascular endothelial growth factor in ossification, Inter. J. Oral. Sci., 4: 64-68, 2012.

68- RABIE A.B., LEUNG F.Y. and CHAYANUPATKUL A.: The correlation between neovascularization and bone formation in the condyle during forward mandibular positioning. Angle Orthod., 72 (5): 431-443, 2002.

69- KANCZLER J.M. and OREFFO R.O.: Osteogenesis and angiogenesis: The potential for engineering bone. Eur. Cell. Mater., 2 (15): 100-114, 2008.

70- RABIE A.B.M., DAI J. and XU R.: Recombinant AAVmediated VEGF gene therapy induces mandibular condylar growth. Gene Ther., 14 (12): 972-980, 2007.

71- OTTO-BUCZKOWSKA E. and CHOBOT A.: Role of ghrelin and leptin in the regulation of carbohydrate metabolism. Part II. Leptin. Postepy Hig. Med. Dosw. (Online), 66: 799-803, 2012.

72- CRESPI E.J. and DENVER R.J.: Leptin (ob gene) of the South African clawed frog Xenopus laevis. Proc. Natl. Acad. Sci., 103: 10092-10097, 2006.

73- BARTELL S.M., RAYALAM S. and AMBATI S.: Central (ICV) leptin injection increases bone formation, bone mineral density, muscle mass, serum IGF-1, and the expression of osteogenic genes in leptin-deficient ob/ob mice. J. Bone Miner. Res., 26: 1710-1720, 2011. 
74- TURNER R.T., KALRA S.P. and WONG C.P.: Peripheral leptin regulates bone formation. J. Bone Miner. Res., 28: 22-34, 2013.

75- PERIYASAMY-THANDAVAN S., HERBERG S. and AROUNLEUT P.: Caloric restriction and the adipokine leptin alter the SDF-1 signaling axis in bone marrow and in bone marrow derived mesenchymal stem cells. Mol. Cell. Endocrinol., 410: 64-72, 2015.

76- CHENG M., LI T., LI W. and CHEN Y.: Leptin can promote mineralization and up-regulate RANKL mRNA expression in osteoblasts from adult female SD rats. Int. J. Clin. Exp. Pathol., 11 (3): 1610-1619, 2018.

\section{تأثير الأوبستاتين على أيض العظام فى الجرذان الطبيعية

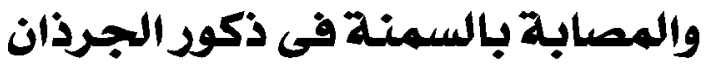 البيضاء البالغة فئمور}

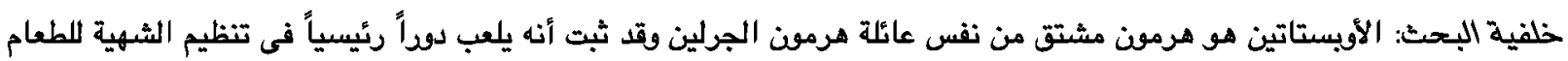

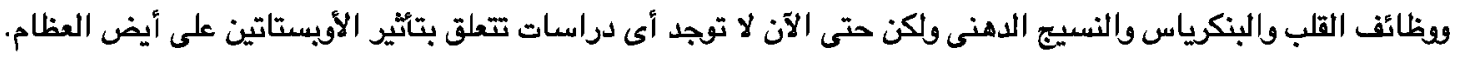

الهدف من البحث: تهدف هذه الدراسة إلى أستكشاف التأثير المحتمل لالؤبستاتين على أيض العظام في الجرذان البيضاء البالغة الطبيعية والمصابة بالسمنة وشرح الآليات المحتملة لهذا التأثير.

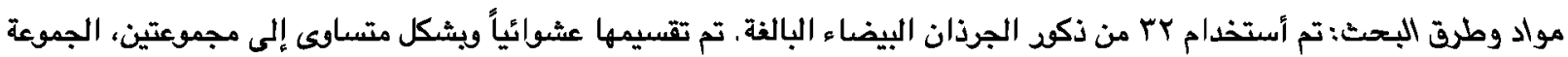

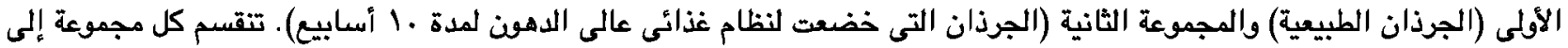

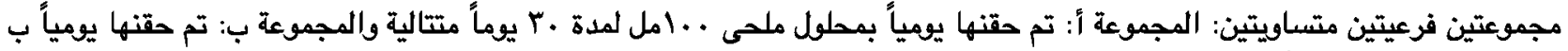

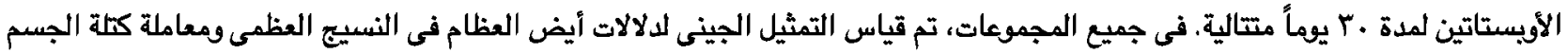

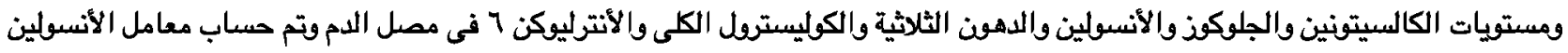
وتم عمل الفحص النسيجى لعينات من نسيج العظام.

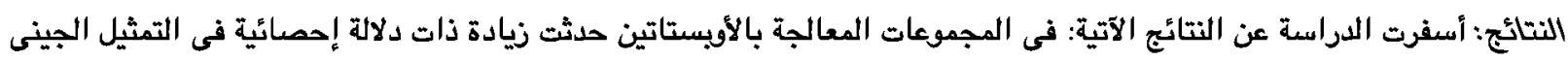

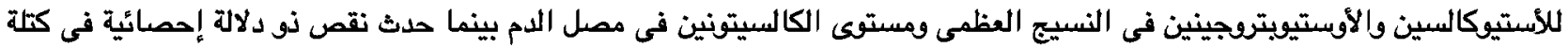

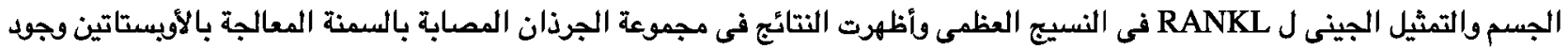

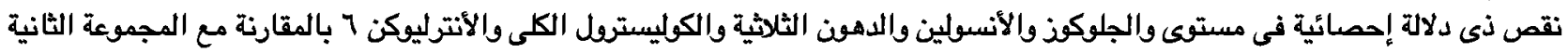

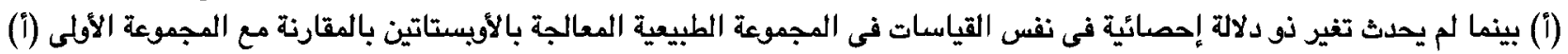

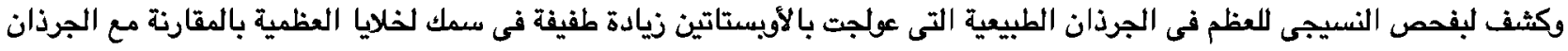

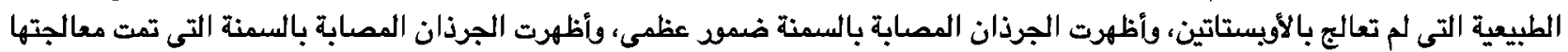

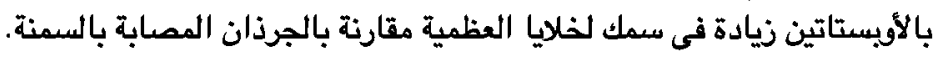

الأستتاج: نستخلص من هذه الدراسة أن الأوبستاتين يعمل على بناء العظام فى الجرذان الطبيعية والمصابة بالسمنة، ويمكن أستخدام

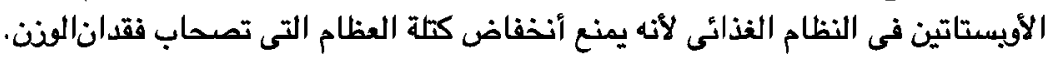

